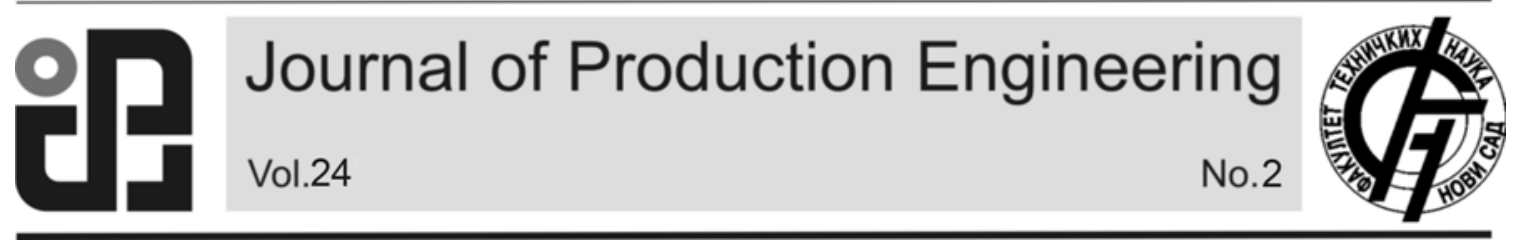

JPE (2021) Vol.24 (2)

Olejárová, ̌̆.

Original Scientific Paper

\title{
ANALYSIS OF MECHANICAL VIBRATION OF A SERVOMOTOR USING VIBROMETRY
}

Received: 01 October 2021 / Accepted: 30 November 2021

\begin{abstract}
The servomotor must ensure resistance to the environment (mechanical vibration, humidity, temperature) in which it will be operated. It is the vibration that is one of the important monitored parameters that allow obtaining initial information about the operational status of the equipment. Exceeding the preset limits adversely affects the service life and reliability of the components. The experimental part is focused on recording and analyzing the magnitude of vibration acceleration, through frequency spectrum and its comparison with the envelopes of frequency spectrums. The obtained graphical dependencies from the experiments are a suitable basis for the assessment of the objective state.
\end{abstract}

Key words: Mechanical vibration, servomotor, vibrometry, vibrometer, frequency spectrum.

Analiza mehaničkih vibracija servomotora primenom vibrometrije. Servomotor mora osigurati otpornost na okolinu (mehaničke vibracije, vlažnost, temperaturu) u kojem će raditi. Vibracije su jedan od važnih nadzoranih parametara koje omogućuju dobivanje početnih informacija o radnom stanju uređaja. Prekoračenje zadanih granica negativno utiče na vek trajanja i pouzdanost komponenti. Eksperimentalni deo je usmeren na snimanje $i$ analizu veličine vibracionog ubrzanja, kroz frekventni spektar i njegovo poređenje sa omotačima frekvencijskih spektra. Dobijene grafičke zavisnosti iz eksperimenata su pogodna osnova za procenu objektivnog stanja.

Ključne reči: Mehaničke vibracije, servomotor, vibrometri, vibrometar, frekvencijski spektar.

\section{INTRODUCTION}

The role of the servomotors as industrial devices is to bring the driven working mechanism (machine) into the specified state of motion in the prescribed manner so that the required technological operation or the required technological process is achieved by the working mechanism. Equipment in operation is negatively affected by various adverse factors [1]. Among the most common factors that have a negative effect on the machinery that performs the movement are vibrations [2]. By measuring and afterward analyzing the magnitude of the vibrations (speed and acceleration), important information about the device is obtained, with the help of which its state can be determined $[3,4]$. Computer control of unattended machines, which make flawless decisions and controls, needs information about the status of faults on the servomotors [5,6]. For this reason, it is necessary to pay attention to the diagnostics of the servomotors [7]. Awareness of the problems with mechanical vibration, data collection, and signal analysis is one of the ways to know the principles of vibration processes in systems and then determine how to eliminate them $[8,9,10]$. In our case, the measurement of the magnitude of the vibration acceleration was performed using PDV-100 laser vibrometry at predetermined points of the UP1-Ex servomotor with an applied load and without load, always under the same conditions [11]. By measuring the vibration acceleration at four measuring points, a frequency spectrum was obtained, which serves as a basis for the evaluation of experiments and a proposal for the use of obtained data. The analysis of the frequency spectrum approximately determines its frequencies on the structural elements, by means of which not only the initial rates of the magnitude of vibration acceleration, the reference frequency spectrum but also limit rates are defined.

\section{CARRYING OUT OF THE RESEARCH}

Measurements were performed under laboratory operating conditions on an electric servomotor of type UP1-Ex. The applied servomotor load (braking resistor) was generated on a test bench using electric motors, with the rotary speed set in the opposite direction to the speed of the servomotor. The braking resistor was defined at $20 \mathrm{Nm}$ and the duration of one measurement was about 1 minute. The intention was to monitor the magnitude of the vibration acceleration using a PDV100 laser vibrometer, where the results were recorded through the frequency spectrum. The laser vibrometer assembly consists of a vibrometer head placed on a positionable tripod, an evaluation unit - measuring card NI 9233, and a recording control in this case a portable PC. The magnitudes of the vibration accelerations were measured at the three preselected points of the servomotor shown in Figure 1 (bearing part, gearbox, and base plate). Four measurements were made at each point, namely [11]:

1st measurement - closes (direction of rotation to the right) without load.

2nd measurement - opens (direction of rotation to the left) without load.

$3 \mathrm{~d}$ measurement - closes (direction of rotation to the right) with the load. 
4th measurement - opens (direction of rotation to the left) with a load.

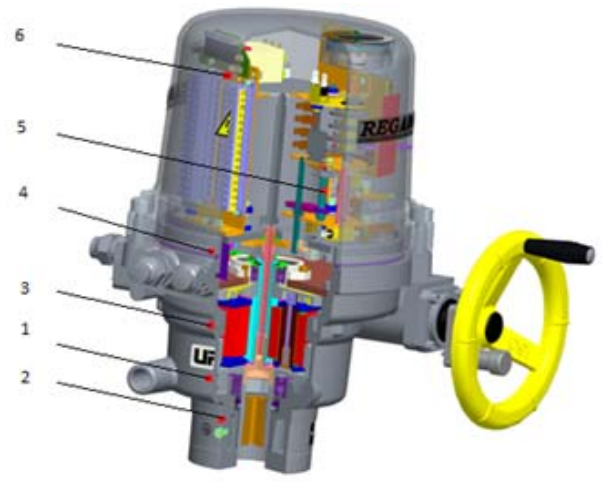

Fig. 1. The selected measuring points of the UP1-Ex actuator

\section{ANALYSIS OF THE RESULTS OF EXPERIMENTAL RESEARCH}

The processing of the measured data consisted of the evaluation of the graphical dependencies from the measured rates of the vibration acceleration amplitudes for the three measured points of the servomotor. It contains an overview of the frequency spectrum obtained by FFT transformation from the time domain in the SignalExpress program in the range of $0-10.000$ Hz. Frequency analysis is given by the amplitude spectrum - amplitude spectral density and phase spectrum. The analysis of the experimental frequency spectrum identifies the speed frequency of the measured site. The spectrum points to the measured rates of the amplitude of the vibration acceleration at individual points and is given without applied load and also with applied load during opening and closing in the run to the right and left of the servomotor [11]. The measured rates of the amplitude of the vibration acceleration on the bearing part (point 1) of the servomotor without load are shown in the graphical dependences Figure. 2 and 3.

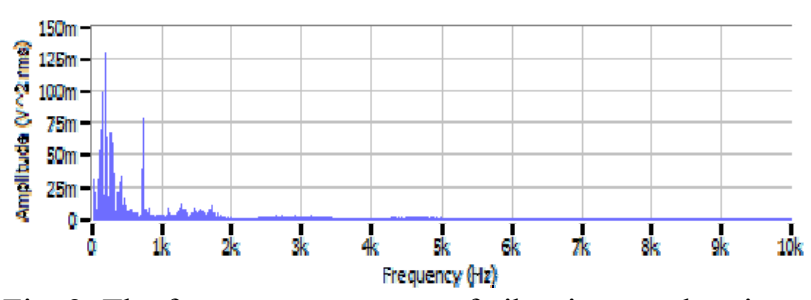

Fig. 2. The frequency spectrum of vibration acceleration at point 1 when opening without load

In the frequency spectrum of Figure. 2 in the frequency range of 0 to $1 \mathrm{kHz}$, several increased amplitudes of vibration acceleration can be seen. The frequency of $24.38 \mathrm{~Hz}$ corresponds to the speed of the electric motor, the magnitude of the acceleration amplitude being $0.03 \mathrm{~g}$. The electric motor is extended with a planetary gearbox, in which the gears appear in the frequency spectrum at several frequencies. At a frequency of approximately $165 \mathrm{~Hz}$, the central wheel engages with a satellite, where the magnitude of the vibration acceleration is $0.1 \mathrm{~g}$. At this frequency, the sidebands ( \pm pinion rotor frequency) emerge, which are probably caused by variable torque or inaccuracy of gear manufacturing. The crown wheel engages with a satellite at a frequency of $4.5 \mathrm{~Hz}$ and the magnitude of the vibration acceleration is negligible. In addition to the gearbox of torque from the electric motor to the central wheel of the planetary gearbox, gears are added output in the frequency spectrum at frequencies of 731 $\mathrm{Hz}$ with a vibration acceleration amplitude of $0.8 \mathrm{~g}$ and $1.292 \mathrm{~Hz}$ of $0.01 \mathrm{~g}$.

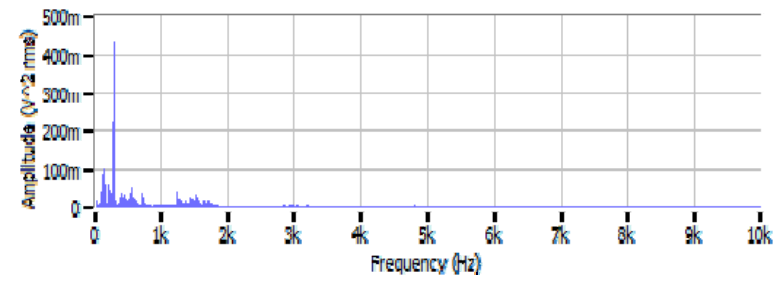

Fig. 3. The frequency spectrum of vibration acceleration at point 1 when closing without load

The frequency spectrum in Figure. 3 shows the largest rates of the amplitude of vibration acceleration in the range of $0-1 \mathrm{kHz}$, where the most significant rate is $0.43 \mathrm{~g}$ and outputs at a frequency of about $300 \mathrm{~Hz}$. The increased rates are also in the frequency range of 165 $\mathrm{Hz}$ with a size of $0.1 \mathrm{~g}$.

The measured rates of the amplitude of vibration acceleration on the bearing part of the servomotor with applied load are shown in the graphical dependences Figure. 4 and 5.

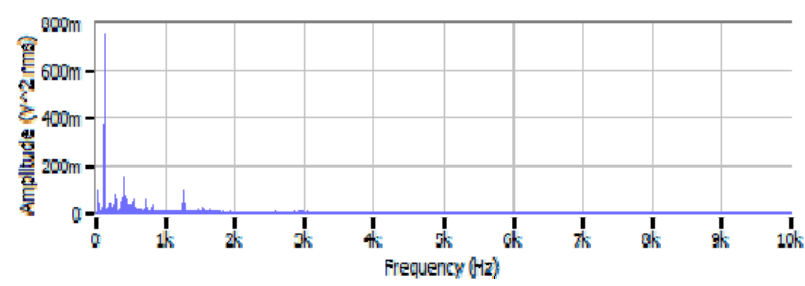

Fig. 4. The frequency spectrum of vibration acceleration at point 1 when opening with applied load

In the frequency spectrum of Figure. 4 there are several higher amplitudes of vibration acceleration. The speed frequency of the electric motor is $23.9 \mathrm{~Hz}$ with a magnitude of vibration acceleration of $0.08 \mathrm{~g}$. The largest magnitude of the vibration acceleration is approximately at a frequency of $161 \mathrm{~Hz}$, and that is 0.77 g. Other significant vibrational accelerations belong to frequencies of approximately $450 \mathrm{~Hz}$ and $1267 \mathrm{~Hz}$. At $450 \mathrm{~Hz}$ the magnitude of the vibration acceleration is $0.18 \mathrm{~g}$ and at $1267 \mathrm{~Hz}$ it is $0.07 \mathrm{~g}$. These frequencies correspond to the gear frequencies of the planetary gearbox.

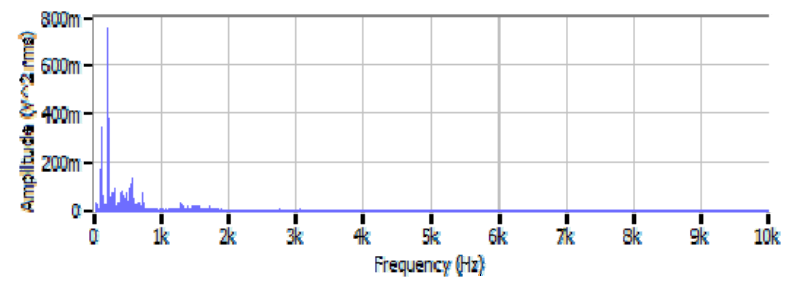

Fig. 5. The frequency spectrum of vibration acceleration at point 1 when closing with applied load 
The frequency spectrum in Figure. 5 shows several increased vibration acceleration amplitudes corresponding to frequencies of approximately $100 \mathrm{~Hz}$, $200 \mathrm{~Hz}, 400 \mathrm{~Hz}$. The magnitude of the vibration acceleration at a frequency of $100 \mathrm{~Hz}$ is $0.35 \mathrm{~g}$. The frequency of $200 \mathrm{~Hz}$ corresponds to a magnitude of vibration acceleration of $0.78 \mathrm{~g}$ and the frequency of $400 \mathrm{~Hz}$ corresponds to $0.11 \mathrm{~g}$.

The measured rates of the amplitude of the vibration acceleration on the gearbox part (point 2) of the servomotor without applied load are shown in the graphical dependences Figure. 6 and 7.

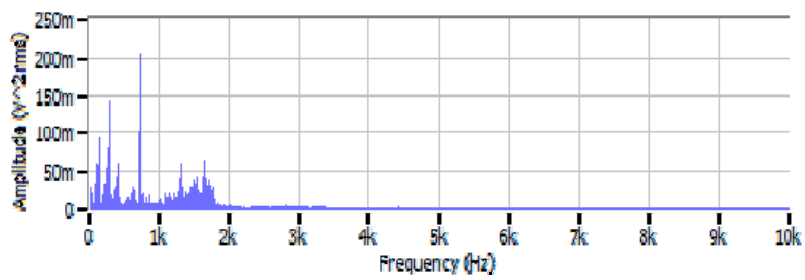

Fig. 6. The frequency spectrum of vibration acceleration at point 2 when opening without applied load

Frequency spectrum Figure. 6 captures at frequencies belonging to tooth and rotational speed frequencies in the range of $0-2 \mathrm{kHz}$, the amplitudes of the vibration acceleration. At the point of $24.35 \mathrm{~Hz}$, the magnitude of the vibration acceleration amplitude of $0.023 \mathrm{~g}$ is shown at the speed of the electric motor. Furthermore, we can observe tooth frequencies and their peripheral ranges on the frequency spectrum. The tooth frequency in the region of $164 \mathrm{~Hz}$ reaches a rate of vibration acceleration of $0.14 \mathrm{~g}$. The $730 \mathrm{~Hz}$ range generates $0.21 \mathrm{~g}$ vibration acceleration magnitudes. Increased rates can be observed even at higher frequencies, for example in the region of $1290 \mathrm{~Hz}$ and higher, where the magnitudes of vibration acceleration reach the magnitude of $0.052 \mathrm{~g}$.

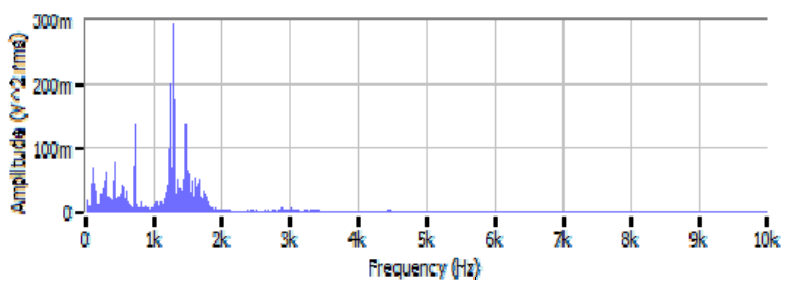

Fig. 7. The frequency spectrum of vibration acceleration at point 2 when closing without applied load

In Figure. 7 is a captured frequency spectrum when closed without applying load, this has vibration acceleration amplitudes different from the frequency spectrum in Figure. 6 when opening without applied load, but outputs in the same frequencies. At $24.35 \mathrm{~Hz}$, the recorded amplitude rate is $0.02 \mathrm{~g}$. The $164 \mathrm{~Hz}$ frequency range generates a vibration acceleration of $0.078 \mathrm{~g}$. Significant amplitudes can be observed at the frequency of $730 \mathrm{~Hz}$ and in the region of $1290 \mathrm{~Hz}$ and its peripheral ranges. The frequency of $730 \mathrm{~Hz}$ reaches an amplitude of $0.13 \mathrm{~g}$ and the maximum rate of the vibration acceleration is $0.29 \mathrm{~g}$ at the point of $1290 \mathrm{~Hz}$.
The measured rates of the amplitude of vibration acceleration on the gearbox of the servomotor with applied load are shown in the graphical dependencies Figure. 8 and 9.

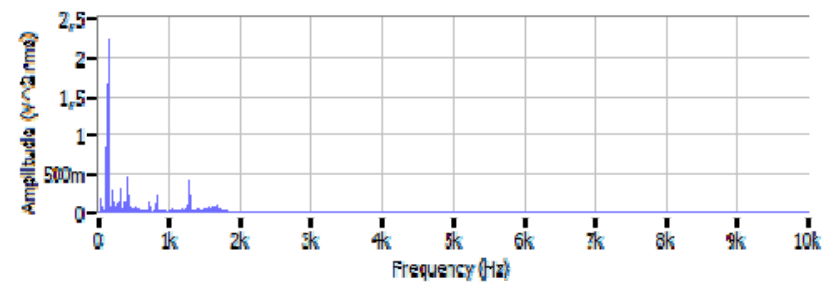

Fig. 8. The frequency spectrum of vibration acceleration at point 2 when opening with applied load

The frequency spectrum in Figure. 8 shows significant increase in vibration acceleration amplitudes. The highest amplitude is recorded in the frequency range of $161 \mathrm{~Hz}$ with a size of $2.23 \mathrm{~g}$. Other frequencies in the range $200 \mathrm{~Hz}-400 \mathrm{~Hz}$ also have increased amplitudes, with the highest being $0.45 \mathrm{~g}$. At higher frequencies around $1266 \mathrm{~Hz}$ we can observe a magnitude of vibration acceleration of $0.4 \mathrm{~g}$.

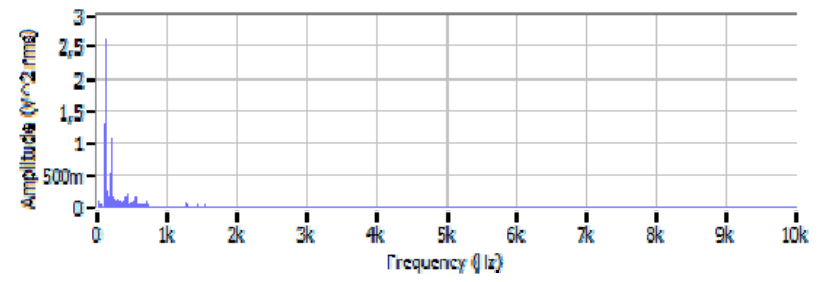

Fig. 9. The frequency spectrum of vibration acceleration at point 2 when closing with applied load

Frequency spectrum Figure. 9 in the range of $0-1$ $\mathrm{kHz}$ shows more significant amplitudes at the frequency of $161 \mathrm{~Hz}$ and its peripheral ranges. At a frequency of $161 \mathrm{~Hz}$, we can observe the magnitude of the amplitude of the vibration acceleration of $2.6 \mathrm{~g}$. A significant amplitude is also found at a frequency of $200 \mathrm{~Hz}$ with a size of $0.11 \mathrm{~g}$.

The measured rates of the amplitude of vibration acceleration on the base plate (point 3) of the servomotor without applied load are shown in the graphical dependencies Figure. 10 and 11.

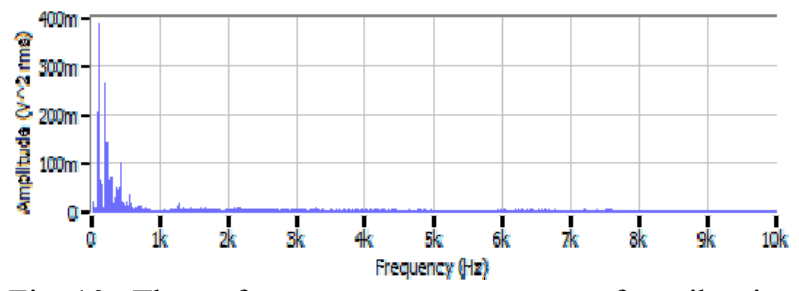

Fig. 10. The frequency spectrum of vibration acceleration at point 3 during unloaded opening

Figure. 10 shows the frequency spectrum where we can see several increased amplitudes in the range of $0-1$ $\mathrm{kHz}$. When opening in the range of $164 \mathrm{~Hz}$, we can see significant amplitudes of vibration acceleration, where the highest rate is $0.38 \mathrm{~g}$. Other more significant amplitudes can be seen in the frequency range of 
approximately $200 \mathrm{~Hz}, 240 \mathrm{~Hz}, 400 \mathrm{~Hz}, 730 \mathrm{~Hz}$ and $1290 \mathrm{~Hz}$. The frequency range of $200 \mathrm{~Hz}$, shows a vibration acceleration of $0.26 \mathrm{~g}$. At $240 \mathrm{~Hz}$, the magnitude of the vibration acceleration is $0.07 \mathrm{~g}$. In the $400 \mathrm{~Hz}$ range, the amplitude is slightly higher and is 0.1 g. At higher frequencies $580 \mathrm{~Hz}$, the magnitude of the amplitude is $0.03 \mathrm{~g}$ and at a frequency of $1.290 \mathrm{~Hz}$, it is $0.015 \mathrm{~g}$.

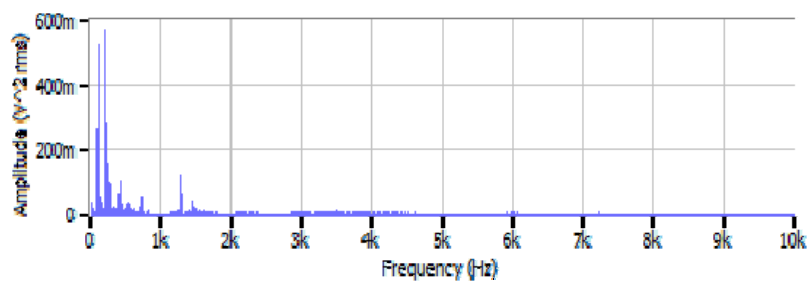

Fig. 11. The frequency spectrum of vibration acceleration at point 3 when closing without applied load

Significant amplitudes of vibration acceleration are shown in Figure. 11, where the size of $0.52 \mathrm{~g}$ belongs to a frequency range of approximately $100 \mathrm{~Hz}$. At a frequency of approximately $200 \mathrm{~Hz}$, the vibration acceleration reaches $0.56 \mathrm{~g}$. Furthermore, we can see the amplitudes of lower rates in the range of $300 \mathrm{~Hz}, 400$ $\mathrm{Hz}$ and $1300 \mathrm{~Hz}$. At $300 \mathrm{~Hz}$, the amplitude reaches a magnitude of $0.15 \mathrm{~g}$ and a vibration acceleration magnitude of $0.1 \mathrm{~g}$ was achieved at a frequency of 400 $\mathrm{Hz}$. In the higher frequency range of approximately $1.300 \mathrm{~Hz}$, the amplitude rate is $0.12 \mathrm{~g}$.

The measured rates sof the amplitude of the vibration acceleration on the base plate of the actuator with load are shown in the graphical dependencies Figure. 12 and 13.

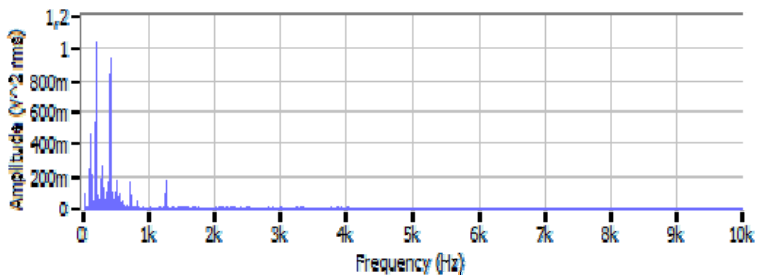

Fig. 12. The frequency spectrum of vibration acceleration at point 3 when opening with applied load

The frequency spectrum shown in Figure. 12 indicates several increased amplitudes. When opening with applied load, the vibration acceleration of $0.1 \mathrm{~g}$ corresponds to a speed of $23.9 \mathrm{~Hz}$ for the electric motor.Other significant amplitudes include the gear frequencies of the planetary gearbox. The $161 \mathrm{~Hz}$ range and peripheral ranges show the highest vibration acceleration amplitude of $1.03 \mathrm{~g}$. In the region of 400 $\mathrm{Hz}$ we can also see a significant amplitude of $0.93 \mathrm{~g}$. The frequencies $730 \mathrm{~Hz}$ and $1290 \mathrm{~Hz}$, after rounding, have the same magnitude of the amplitude of the vibration acceleration of $0.16 \mathrm{~g}$.

In the frequency spectrum of Figure. 13, we can see especially in the range of $0-1 \mathrm{kHz}$ several higher amplitudes. At a significant frequency of $100 \mathrm{~Hz}$, the rate of vibration acceleration reaches $2.59 \mathrm{~g}$. The amplitude of the vibration acceleration of $1.06 \mathrm{~g}$ belongs to a frequency of $200 \mathrm{~Hz}$.

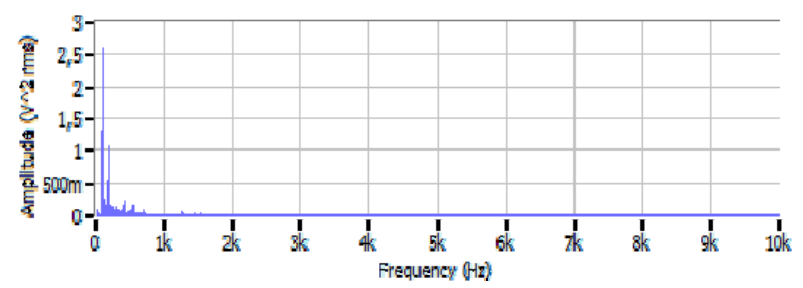

Fig. 13. The frequency spectrum of vibration acceleration at point 3 when closing with applied load

The envelope method was used as an additional level to evaluate the measured values. It consists of measuring shock pulses that occur during the operation of servomotors. The signal is first ignited to a filter, which transmits only high frequencies and removes most of the noise. After rectification, it changes to an envelope, where the energy is reduced, but the pulses are repeated at the same intervals, or the frequency of the repeated signal is not changed by filtering. The envelope spectrum is obtained by FFT analysis, which contains a component where frequency indicates kinetic frequencies. The graphs in Figure. 14 to 19 show the amplitudes of the vibration acceleration as a function of the frequency, by means of which the measured rates of the vibration acceleration are compared with the servomotor running to the right or left. The envelopes are designed for better overview only in the frequency range of $0-2000 \mathrm{~Hz}$, since from the previous observations in Figure 1., 2 to 13, it can be seen that higher rates of the amplitude of the vibration acceleration are recorded in this spectrum. A comparison graph of the load-free frequency spectrum of envelopes for the Ybearing part of the servomotor is shown in Figure. 14.

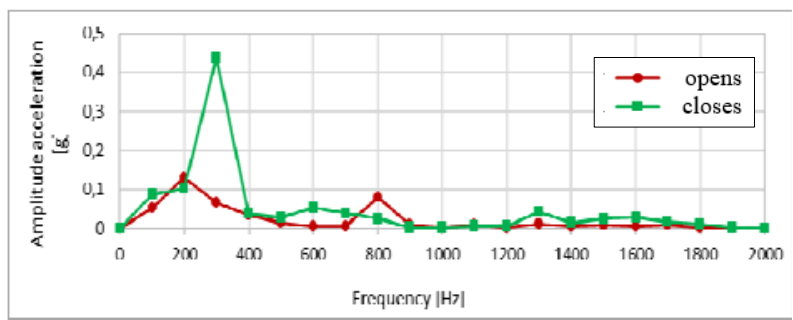

Fig. 14. Comparison graph of frequency spectrum envelopes for measured point 1 without applied load

The rates of the vibration acceleration during opening and closing can be figured from the comparison graph of the frequency spectrum of envelopes Figure. 14. When opening, the maximum rate of the vibration acceleration is $0.13 \mathrm{~g}$ at a frequency of approximately $200 \mathrm{~Hz}$. A more significant rate is also the acceleration of vibrations of $0.78 \mathrm{~g}$ at a frequency of approximately $800 \mathrm{~Hz}$. When closing, the amplitude of the vibration acceleration increased significantly to $0.43 \mathrm{~g}$, at a frequency of approximately $300 \mathrm{~Hz}$. After analyzing the 
comparison graph, it is clear that the rates of vibration acceleration are higher when closing than when opening. The mentioned rates of vibration acceleration during opening or closing correspond to the frequencies of the planetary gearbox.

A comparison graph of the frequency spectrum of envelopes with applied load on the bearing part of the servomotor is shown in Figure. 15.

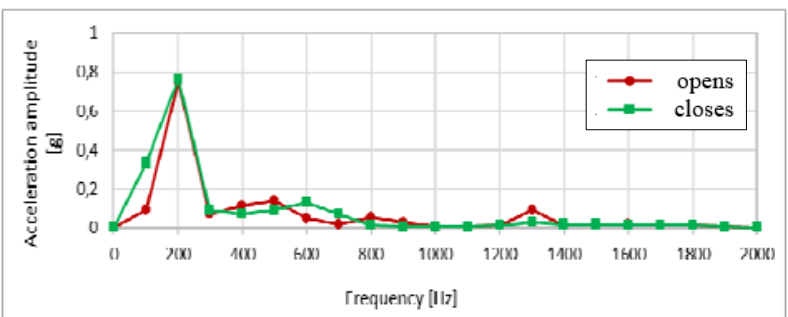

Fig. 15. Comparison graph of the frequency spectrum of envelopes with applied load on measured point 1

From the comparison graph of the frequency spectrum of envelopes, Figure. 15, the difference in the magnitude of the vibration acceleration during opening and closing can be determined. When opening, the maximum rate of the vibration acceleration is $0.74 \mathrm{~g}$ at a frequency of approximately $200 \mathrm{~Hz}$. The vibration acceleration is also increased at a frequency of $500 \mathrm{~Hz}$ with a rate of $0.14 \mathrm{~g}$ and at a frequency of $1300 \mathrm{~Hz}$ is $0.09 \mathrm{~g}$. When closing, the maximum rate is also at a frequency of approximately $200 \mathrm{~Hz}$ and its size is 0.76 g. Another significant frequency is $600 \mathrm{~Hz}$, where the magnitude of the vibration acceleration reaches $0.13 \mathrm{~g}$. After analyzing the comparison graph, it is clear that they do not differ much when closing and opening the vibration acceleration.

A comparison graph of the frequency spectrum of envelopes without applied load on the gearbox of the servomotor is shown in Figure. 16.

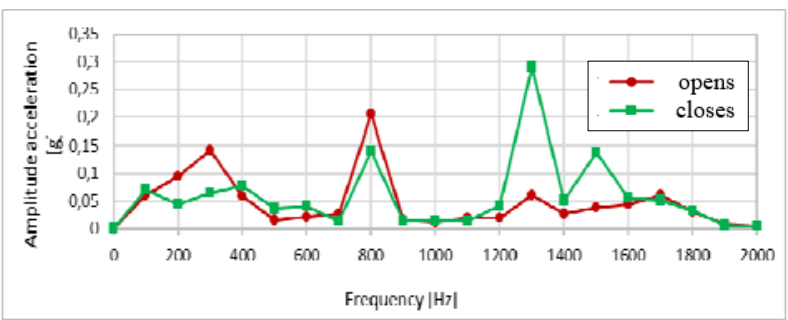

Fig. 16. Comparison graph of frequency spectrum without applied load of envelopes on measured point 2

From the comparison graph of the frequency spectrum of envelopes, Figure. 16, the magnitude of the vibration acceleration amplitude can be determined for the corresponding frequencies. When opening, we can observe several increased amplitudes. The curve has an increasing character from the frequency of $100 \mathrm{~Hz}$, where the rate of the vibration acceleration reached the rate of $0.06 \mathrm{~g}$ up to the range of $300 \mathrm{~Hz}$, the magnitude of the vibration acceleration of which is $0.14 \mathrm{~g}$. At a frequency of $400 \mathrm{~Hz}$, the acceleration rate decreased and its rate is $0.059 \mathrm{~g}$. A more significant increase can be observed in the range of $800 \mathrm{~Hz}$ and $1.300 \mathrm{~Hz}$. The $800 \mathrm{~Hz}$ range represents the highest amplitude of vibration acceleration of $0.2 \mathrm{~g}$. In the region of $1.300 \mathrm{~Hz}$ it reaches $0.06 \mathrm{~g}$. When closing, the dependence of the vibration acceleration on the frequency has a fluctuating character. In the frequency range of $100 \mathrm{~Hz}$ and $400 \mathrm{~Hz}$, the amplitudes differ only slightly from the amplitudes during opening. The largest amplitude differences are set in the ranges of $800,1.300$ and $1.500 \mathrm{~Hz}$. At a frequency of $800 \mathrm{~Hz}$, the amplitude dropped to $0.14 \mathrm{~g}$ at the time of closing. On the contrary, the amplitude increased with a vibration acceleration rate of $0.29 \mathrm{~g}$ at a frequency of $1.300 \mathrm{~Hz}$ and also increased at a frequency of $1.500 \mathrm{~Hz}$ to $0.13 \mathrm{~g}$. After analyzing the comparative, it can be stated that the curves of the opening and closing curves are similar, while the largest difference can be seen at the frequency of $1.300 \mathrm{~Hz}$ and $1.500 \mathrm{~Hz}$.

A comparison graph of the frequency spectrum of envelopes with applied load on the transmission part of the servomotor is shown in Figre . 17.

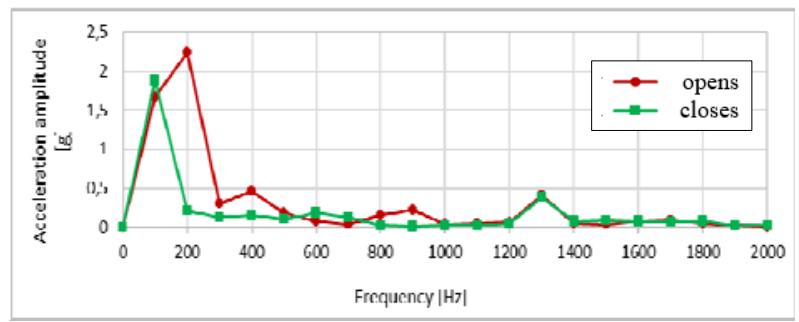

Fig. 17. Comparison graph of the frequency spectrum of envelopes with applied load for measured point 2

From the comparison graph of the frequency spectrum of envelopes, Figure. 17, we can determine the magnitude of the amplitude of the vibration acceleration when opening and closing the servomotor. The highest amplitude while opening is $2.23 \mathrm{~g}$ at a frequency of 200 $\mathrm{Hz}$. Significant amplitudes of vibration acceleration are also at frequencies of $100 \mathrm{~Hz}$ with a size of $1.66 \mathrm{~g}$, at a frequency of $400 \mathrm{~Hz}$ with a magnitude of vibration acceleration of $0.45 \mathrm{~g}$, at a frequency of $700 \mathrm{~Hz}$ the amplitude is $0.22 \mathrm{~g}$ and at $1300 \mathrm{~Hz}$ it is $0.4 \mathrm{~g}$. When closing, the amplitude of the vibration acceleration reaches a maximum at a frequency of $100 \mathrm{~Hz}$ of $1.88 \mathrm{~g}$. A more significant frequency is also the frequency of $1300 \mathrm{~Hz}$, where the magnitude of the vibration acceleration reaches $0.38 \mathrm{~g}$. After analyzing the comparison graph, it is clear that the rates differ only slightly when closing and opening the servomotor. The largest difference can be seen at a frequency of $200 \mathrm{~Hz}$.

A comparison graph of the frequency spectrum of envelopes without applied load on the servomotor's base plate is shown in Figure. 18.

From the comparison graph of the frequency spectrum of envelopes, Figure. 18, we can subtract the amplitude acceleration rates at a certain frequency. When opening the servomotor, the maximum rate of the amplitude of the vibration acceleration reached $0.38 \mathrm{~g}$ at a frequency of $100 \mathrm{~Hz}$. Significant rates of vibration acceleration can also be observed at the frequency of $200 \mathrm{~Hz}, 300 \mathrm{~Hz}$ and $400 \mathrm{~Hz}$. At a frequency of $200 \mathrm{~Hz}$, 
the rate of the vibration acceleration is $0.26 \mathrm{~g}$. The rate of $0.06 \mathrm{~g}$ corresponds to a frequency of $300 \mathrm{~Hz}$ and at a frequency of $400 \mathrm{~Hz}$ the amplitude reaches a size of $0.09 \mathrm{~g}$. When closing the servomotor, the frequencies reach higher rates of vibration acceleration. At $100 \mathrm{~Hz}$, the amplitude is $0.52 \mathrm{~g}$. The magnitude of the vibration acceleration increased to a frequency of $200 \mathrm{~Hz}$ and its rate is $0.56 \mathrm{~g}$. Furthermore, we can see a decrease in the magnitude of the vibration acceleration. At a frequency of $300 \mathrm{~Hz}$, the vibration acceleration is $0.15 \mathrm{~g}$. Significant areas can still be seen in the ranges of 400 $\mathrm{Hz}$ and $1.300 \mathrm{~Hz}$. At $400 \mathrm{~Hz}$, the amplitude rate reaches $0.1 \mathrm{~g}$, and in the $1.300 \mathrm{~Hz}$ range, the magnitude of the vibration acceleration is $0.12 \mathrm{~g}$. The vibration acceleration patterns during opening and closing are similar. The largest difference can be observed at the frequency of $100 \mathrm{~Hz}, 200 \mathrm{~Hz}$ and $1.300 \mathrm{~Hz}$.

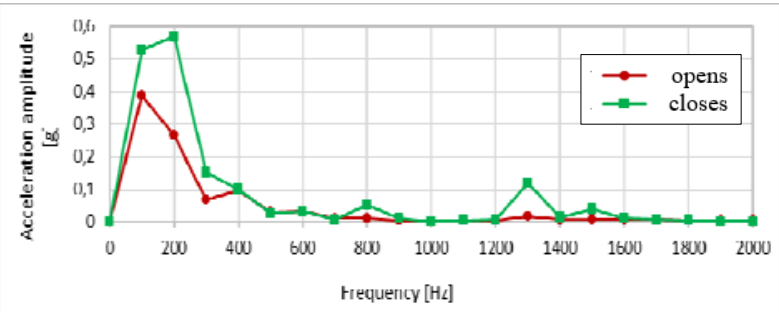

Fig. 18. Comparison graph of the frequency spectrum of envelopes without applied load on the measured point 3

A comparison graph of the frequency spectrum of envelopes with applied load on servomotor's base plate is shown in Figure. 19.

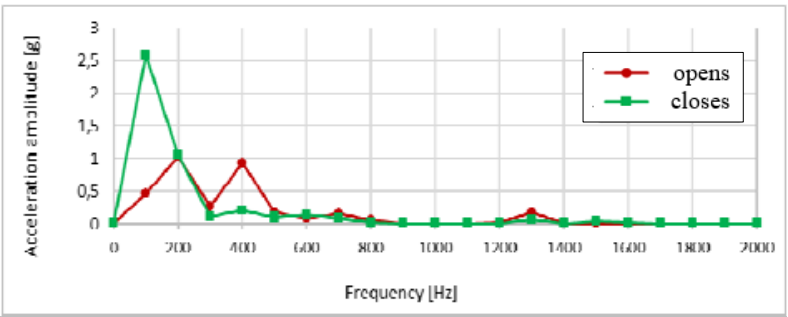

Fig. 19. Comparison graph of the frequency spectrum of envelopes with applied load on the measured point 3

In the comparison graph of the frequency spectrum of envelopes, Figure. 19, we can see fluctuating rates of vibration acceleration in the ranges of $0-400 \mathrm{~Hz}$. When opening at the maximum rate of vibration acceleration of $1.03 \mathrm{~g}$ we can see a frequency of $200 \mathrm{~Hz}$. A slightly lower rate of the vibration acceleration of $0.93 \mathrm{~g}$ belongs to the frequency of $400 \mathrm{~Hz}$. An interesting rate is also the vibration acceleration of $0.45 \mathrm{~g}$, which corresponds to a frequency of $100 \mathrm{~Hz}$. When closing the servomotor, the course has a more stable character. The maximum rate of the vibration acceleration is $2.59 \mathrm{~g}$ at a frequency of $100 \mathrm{~Hz}$. The amplitude of the vibration acceleration of $1.06 \mathrm{~g}$ is at a frequency of $200 \mathrm{~Hz}$. After analyzing the comparison graph, we can state that the difference in amplitude during opening and closing is more significant at the frequency of $100 \mathrm{~Hz}$ and $400 \mathrm{~Hz}$.

\section{CONCLUSION}

The report pays great attention to measuring the magnitude of vibration acceleration on the UP1-Ex servomotor. As this is a new servomotor that has not been applied to operation yet and serves as a model, it is appropriate to consider those frequency spectra as a reference frequency spectrum. These reference spectra define the approximate initial rates of the vibration acceleration amplitudes at the frequencies assigned to the servomotor component. Long-term monitoring can define the deteriorating course of these vibration acceleration rates. Vibration acceleration rates cannot exceed the limit rate. The limit by which the acceleration rates can be increased from the reference rate is given in ISO 13373-1:2002. If the vibration acceleration at the local frequency increases 2.5 times from the reference rate, this is an important change of state. If the reference rate is exceeded 10 times, service intervention or replacement of the component is necessary. The moving parts of the servomotor generate vibrations at their own frequencies. The reason for vibration can be, for example, inaccuracy caused during the production of structural elements (tolerances), insufficient rigidity of the elements, mechanical play, resonance, etc. In this work, the frequencies of the components are determined approximately. A more detailed determination of local frequencies may be the subject of further investigation of this issue.

\section{REFERENCES}

[1] Skalický, J.: Elektrické pohony a výkonová elektronika: súčasný stav, perspektivity a výuka. Brno: VUTIUM 2000. ISBN 80-214-1601-7

[2] Jamrichová, Z., Stodola, J., Stodola, P.: Diagnostika strojov a zariadení. Žilina: EDIS 2011, 281 s. ISBN 978-80-554-0385-4

[3] Zahradníček, R.: Problémy technickej diagnostiky s dôrazom na vibrodiagnostiku. Košice: Vojenská letecká akadémia gen. M.R. Štefánika 2001, 108 s. ISBN 80-7166-039-6

[4] Trebuňa, F., Huňady, R., Hagara, M., Pástor, M.: Experimentálne metódy mechaniky - Laserová vibrometria a ESPI. Košice: Technická univerzita v Košiciach 2015, 183 s. ISBN 978-80-553-2347-3

[5] Kanović, Ž., Matić, D., Jeličić, Z., , Petković M.: Dijagnostika kvarova asinhronih motora zasnovana na analizi vibracija - primer iz prakse. Journal on Processing and Energy in Agriculture, 2013, vol. 17, pp. 47-50

[6] Tavner, P.J., Penman, J.: Condition monitoring of electrical machines. Wiley and Sons, UK, 1987

[7] Finley, W.R., Hodowanec, M.M., Holter, W.G.: An analytical approach to solving motor vibration problems. IEEE Transactions on Industry Applications, 36 (5), 2000, pp. 1467-1480

[8] Hachemi, B.M.: A review of induction motors signature analysis as a medium for faults detection. IEEE Transactions on Industrial Electronics, 47(5). 2000. pp 984-993

[9] Kanović, Ž., Jakovljević, B., Rapaić, M., Jeličić, Z.: Expert system for induction motor fault detection 
based on vibration analysis. Journal on Processing and Energy in Agriculture, vol. 16, 2012, str. 36-40

[10] Bonnett, A.H., Soukup, G.C.: Analysis of rotor failures in squirrel-cage induction motors. IEEE Transactions on Industry Applications, 24(6), 1988. 1124-1130

[11] Kamenický, J.: Meranie a analýza mechanického kmitania servopohonu pomocou vibrometrie. Záverečná diplomová práca. Vedúci práce: Štefánia Olejárová. FVT TUKE Prešov. 2016

\section{ACKNOWLEDGEMENT}

This work was supported by the Slovak Ministry of Education within project VEGA No. 1/0823/21 and by the Slovak Research and Development Agency under contract No. APVV-18-0316.

Authors: Ing. Štefánia Olejárová, Phd., Technical University of Košice, Faculty of Manufacturing Technologies, Department of Manufacturing Processes Operation, Bayerova 1, 08001 Prešov, Slovakia, Phone.: +421 556026313

E-mail: stefania.olejarova@tuke.sk 